Article

\title{
Dissimilarity of Ant Communities Increases with Precipitation, but not Reduced Land-Use Intensity, in Indonesian Cacao Agroforestry
}

\author{
Akhmad Rizali ${ }^{1,2, *}$, Yann Clough ${ }^{1}$, Damayanti Buchori ${ }^{2}$ and Teja Tscharntke ${ }^{1}$ \\ 1 Agroecology, Department of Crop Science, University of Göttingen, Grisebachstrasse 6, D-37077, \\ Göttingen, Germany; E-Mails: yclough@gwdg.de (Y.C.); ttschar@gwdg.de (T.T.) \\ 2 Department of Plant Protection, Faculty of Agriculture, Bogor Agricultural University, Kampus \\ IPB Dramaga, Bogor, 16680, West Java, Indonesia; E-Mail: dami@indo.net.id (D.B.) \\ * Author to whom correspondence should be addressed; E-Mail: arizali@gwdg.de; \\ Tel.: +49-551-393-739; Fax: +49-551-398-806.
}

Received: 12 November 2012; in revised form: 28 December 2012 / Accepted: 22 January 2013 / Published: 31 January 2013

\begin{abstract}
Land-use degradation and climate change are well-known drivers of biodiversity loss, but little information is available about their potential interaction. Here, we focus on the effects of land-use and precipitation on ant diversity in cacao agroforestry. In Central Sulawesi, Indonesia, we selected 16 cacao agroforestry plots with a shaded $v s$. unshaded plot in each of eight villages differing in precipitation (1032-2051 mm annual rainfall). On each plot, 10 cacao trees with similar size and age (7-10 years) were selected for hand collection of ants on each cacao tree and the soil surface. In total, we found 80 ant species belonging to five subfamilies. Land-use intensification (removal of shade trees) and precipitation had no effect on species richness of ants per cacao tree (alpha diversity) and, in an additive partitioning approach, within-plot beta diversity. However, higher precipitation (but not shade) significantly increased ant species dissimilarity across cacao trees within a plot, with ant species showing contrasting responses to precipitation. Reduced precipitation causing drought stress appeared to contribute to convergence of ant community structure, presumably via reduced heterogeneity in cacao tree growth. In conclusion, reduced precipitation greatly influenced ant community dissimilarity and appeared to be more important for ant community structure than land-use intensification.
\end{abstract}

Keywords: alpha diversity; beta diversity; community dissimilarity; land-use; precipitation 


\section{Introduction}

Land-use degradation and climate change are well-known drivers of biodiversity loss [1]. Temperature increase and reduced precipitation can have an effect on the distribution, reproduction and behavior of species [2], and may even favor invasive species that are able to adapt to this altered environment [3]. However, little is known of the interaction of land-use degradation and climate change, although both together may greatly increase biodiversity losses [4].

In agricultural ecosystems, land-use intensification, exacerbated by climate change effects, may severely affect functional biodiversity, for example, natural enemies providing successful biological control. Increasing carbon dioxide and temperature can also facilitate the presence of pests and diseases in agricultural habitat and reduce agrobiodiversity [5]. In addition, climate change can have direct effect on crop plant growth through increased temperature, drought, rainfall and tropical storms [5].

Agroforestry systems can provide suitable habitat for biodiversity [6] and may mitigate effects of climate change [7]. However, this depends on the management. Agroforestry intensification by shade tree removal [7,8] and pesticide application [9] has particularly adverse effects on biodiversity. This may have functional consequences, especially if organisms important for pest regulation, such as ants [10], are affected. Bos et al. [11] found that decreasing shade-tree cover negatively affects ant diversity in cacao agroforestry. Wielgoss et al. [12] suggest that ant diversity in cacao agroforestry is affected more by temperature than decreasing numbers of shade trees. In general, however, the joint role of climate and shade-tree loss in affecting ant species communities has not been addressed, despite its potential significance in ecosystem response to changing rainfall patterns and land-use change.

In this study, we analyze how land-use change and precipitation affect ant diversity in agroforestry. We selected 16 cacao agroforestry plots located in eight villages around Lore Lindu National Park (LLNP) in Central Sulawesi, Indonesia. In each village, we studied one shaded and one unshaded agroforestry system, while the eight villages were situated along a precipitation gradient. We asked the following questions: (i) How does ant community structure change along land-use intensity and precipitation gradients? (ii) Does the ant communities on the cacao tree and on the ground show different responses? (iii) Which ant species show the strongest responses to the precipitation gradient?

\section{Experimental Section}

\subsection{Study Sites}

The 16 studied plots were cacao agroforestry systems located in eight villages around the Lore Lindu National Park (LLNP), Central Sulawesi, Indonesia (Figure 1). The agroforestry systems differed in land-use intensity (shaded vs. unshaded) and the villages in precipitation (1032 to 2051 $\mathrm{mm} /$ year) (Table 1). 
Figure 1. Location map of the 16 cacao agroforestry plots in eight villages with different precipitation levels. Villages are located around Lore Lindu National Park, Central Sulawesi, Indonesia.

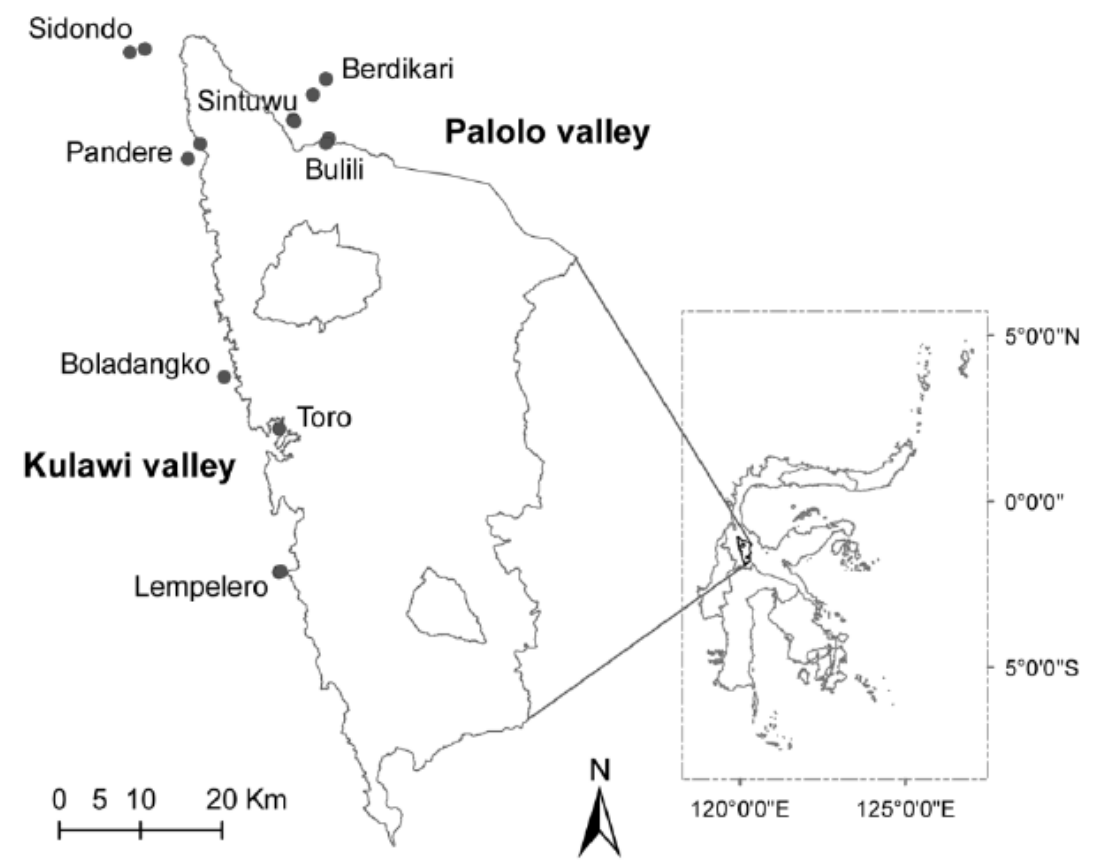

Table 1. Observed and estimated ant species richness of the 16 plots with different landuse (A: shaded; B: unshaded cacao agroforestry) and different precipitation located in eight villages around Lore Lindu National Park, Central Sulawesi, Indonesia.

\begin{tabular}{|c|c|c|c|c|c|c|c|c|}
\hline No & Village & Land-use & $\begin{array}{l}\text { Latitude } \\
\qquad\left({ }^{\circ} \mathbf{S}\right)\end{array}$ & $\begin{array}{l}\text { Longitude } \\
\quad\left({ }^{\circ} \mathbf{E}\right)\end{array}$ & $\begin{array}{l}\text { Altitude } \\
\text { (m asl) }\end{array}$ & $\begin{array}{c}\text { Precipitation } \\
\text { (mm/year) }\end{array}$ & $\begin{array}{c}\text { Observed } \\
\text { species }\end{array}$ & $\begin{array}{c}\text { Estimated } \\
\text { species } \\
(\%) *\end{array}$ \\
\hline \multirow[t]{2}{*}{1.} & Berdikari & A & 01.11693 & 120.09266 & 646 & 2,051 & 24 & $28.5(84.2)$ \\
\hline & & B & 01.13420 & 120.07861 & 603 & & 17 & $25.0(68.0)$ \\
\hline \multirow[t]{2}{*}{2.} & Sintuwu & A & 01.16213 & 120.05642 & 554 & 1,430 & 26 & $32.8(79.4)$ \\
\hline & & B & 01.16339 & 120.05790 & 567 & & 20 & $52.0(38.5)$ \\
\hline \multirow[t]{2}{*}{3.} & Bulili & $\mathrm{A}$ & 01.18261 & 120.09550 & 582 & 1,504 & 17 & $29.3(58.1)$ \\
\hline & & B & 01.18738 & 120.09239 & 652 & & 18 & $22.2(81.2)$ \\
\hline \multirow[t]{2}{*}{4.} & Pandere & A & 01.18844 & 119.95393 & 179 & 1,160 & 21 & $23.1(91.0)$ \\
\hline & & B & 01.20482 & 119.94063 & 102 & & 18 & $19.5(92.3)$ \\
\hline \multirow[t]{2}{*}{5.} & Sidondo & A & 01.08366 & 119.89272 & 41 & 1,032 & 23 & $35.3(65.2)$ \\
\hline & & B & 01.08764 & 119.87599 & 27 & & 16 & $17.5(91.4)$ \\
\hline \multirow[t]{2}{*}{6.} & Boladangko & A & 01.44530 & 119.98057 & 523 & 1,590 & 24 & $44.3(54.2)$ \\
\hline & & B & 01.44499 & 119.98001 & 558 & & 18 & $20.7(87.1)$ \\
\hline \multirow[t]{2}{*}{7.} & Toro & A & 01.50238 & 120.04055 & 800 & 1,704 & 26 & $32.4(80.2)$ \\
\hline & & B & 01.50237 & 120.04109 & 797 & & 21 & $24.1(87.0)$ \\
\hline \multirow[t]{2}{*}{8.} & Lempelero & A & 01.66104 & 120.04093 & 432 & 1,742 & 14 & $16.7(84.0)$ \\
\hline & & B & 01.66035 & 120.04307 & 438 & & 22 & $30.1(73.1)$ \\
\hline
\end{tabular}

* Predicted number of species based on Chao estimator of the 10 cacao trees as sampling unit; \%, sampled species as a percentage of predicted number of species. 


\subsection{Plots Selection and Ant Sampling}

Each cacao agroforestry plot differed in agricultural management because it belonged to a different farmer. On each plot $(5 \mathrm{~m} \times 15 \mathrm{~m}), 10$ cacao trees with similar size and age (7-10 years) were selected for ant observation. Ants were sampled on all strata i.e., the tree trunk and the soil surface (within area $1 \mathrm{~m}$ distance from base of cacao tree) using hand collecting combine with baiting (using tuna and sugar) lasted a maximum of 10 min per tree and conducted both in the morning and afternoon. Hand collection is the best method to record all of ant species inhabiting an area by searching and collecting ants in different microhabitats [13]. Hand collecting was conducted twice in the same cacao trees, in November 2009 and June 2010, to quantify ant species diversity on each cacao tree per plot in different seasons.

Ant specimens were sorted and identified to genus using [14] or were separated according to their external morphology as morphospecies [15]. Some of the ants could be identified to species level with the help of websites (e.g. [16]).

\subsection{Data Analysis}

The completeness of sampling on each plot was calculated using the Chao estimator [17]. To test for spatial autocorrelation, we used the Mantel test [18, 19] based on the distance and ant similarity among plots. Alpha diversity was derived from mean ant species richness per tree, whereas beta diversity was calculated based on an additive diversity portioning approach [20] with beta diversity resulting from gamma diversity (total ant species in one plot) minus alpha diversity (species richness per tree). The Bray-Curtis dissimilarity index was used to calculate the dissimilarity of ant species communities between the ten cacao tree on each plot, using vegan package in R software [21]. Then, we calculated the community dissimilarity using ordihull within non-metric multidimensional scaling (NMDS) (vegan package). Analysis of variance (ANOVA) and linear models (LM) were used to relate ant diversity and community similarity to the land-use and precipitation gradients. Logit regression was performed to analyze the relationship between ant species presence or absence and the precipitation level. All analyses were conducted using R software [21].

\section{Results}

\subsection{Ant Community Structure along Land-Use Intensity and Precipitation Gradients}

In total, we found 80 species belonging to 5 subfamilies in the 16 cacao agroforestry plots (see supplementary material Table S1). The Chao estimate for each plot on almost all 16 sampled cacao agroforestry indicated that these sampling methods captured most of ant species richness (Table 1). Based on the Mantel test, we did not find spatial autocorrelation between similarity of ant communities with nearness distance of plots (Mantel statistic $r=0.161, \mathrm{P}=0.087$ ). We found that mean ant species richness per tree (alpha diversity), beta diversity (richness per plot minus mean richness per tree) and ant species similarity (on the tree and on the soil surface) across the 10 trees per plot were not affected by the presence or absence of shade trees (Table 2). In contrast, precipitation levels significantly 
affected ant community similarity on the tree (but not on the soil surface) in the cacao agroforestry (Table 2).

Table 2. Effects of shade-tree removal, precipitation and altitude on species richness per tree (alpha diversity), beta diversity and community similarity of ant communities in each stratum, based on 16 cacao agroforestry plots.

\begin{tabular}{|c|c|c|c|}
\hline \multirow{2}{*}{ Parameters } & \multicolumn{3}{|c|}{ Strata } \\
\hline & Total & Tree & Soil surface \\
\hline Alpha diversity & & & \\
\hline Land-use & $\mathrm{F}_{1,12}=0.084, \mathrm{P}=0.777$ & $\mathrm{~F}_{1,12}=0.070, \mathrm{P}=0.796$ & $\mathrm{~F}_{1,12}=0.006, \mathrm{P}=0.940$ \\
\hline Precipitation & $\mathrm{F}_{1,12}=0.003, \mathrm{P}=0.957$ & $\mathrm{~F}_{1,12}=0.415, \mathrm{P}=0.532$ & $\mathrm{~F}_{1,12}=0.059, \mathrm{P}=0.813$ \\
\hline Altitude & $\mathrm{F}_{1,12}=0.001, \mathrm{P}=0.982$ & $\mathrm{~F}_{1,12}=0.014, \mathrm{P}=0.907$ & $\mathrm{~F}_{1,12}=1.372, \mathrm{P}=0.264$ \\
\hline Beta diversity & & & \\
\hline Land-use & $\mathrm{F}_{1,12}=4.950, \mathrm{P}=0.046$ & $\mathrm{~F}_{1,12}=1.511, \mathrm{P}=0.243$ & $\mathrm{~F}_{1,1}=2.379, \mathrm{P}=0.149$ \\
\hline Precipitation & $\mathrm{F}_{1,12}=0.223, \mathrm{P}=0.645$ & $\mathrm{~F}_{1,12}=1.708, \mathrm{P}=0.216$ & $\mathrm{~F}_{1,12}=0.134, \mathrm{P}=0.721$ \\
\hline $\begin{array}{l}\text { Altitude } \\
\end{array}$ & $\mathrm{F}_{1,12}=2.779, \mathrm{P}=0.121$ & $\mathrm{~F}_{1,12}=0.286, \mathrm{P}=0.603$ & $\mathrm{~F}_{1,12}=1.980, \mathrm{P}=0.185$ \\
\hline Ant community similarity & & & \\
\hline Land-use & $\mathrm{F}_{1,12}=0.277, \mathrm{P}=0.608$ & $\mathrm{~F}_{1,12}=1.854, \mathrm{P}=0.198$ & $\mathrm{~F}_{1,12}=0.576, \mathrm{P}=0.463$ \\
\hline Precipitation & $\mathrm{F}_{1,12}=5.032, \mathrm{P}=0.045$ & $\mathrm{~F}_{1,12}=7.613, \mathrm{P}=0.017$ & $\mathrm{~F}_{1,12}=0.008, \mathrm{P}=0.932$ \\
\hline Altitude & $\mathrm{F}_{1,12}=1.025, \mathrm{P}=0.331$ & $\mathrm{~F}_{1,12}=0.588, \mathrm{P}=0.458$ & $\mathrm{~F}_{1,12}=0.008, \mathrm{P}=0.932$ \\
\hline
\end{tabular}

There is a positive correlation between precipitation and altitude $\left(\mathrm{F}_{1,14}=21.47, \mathrm{P}=0.0004, \mathrm{r}^{2}=0.58\right)$ (see supplementary material Figure S1). Nevertheless, the better predictor of ant species is precipitation $(\mathrm{df}=5, \mathrm{AIC}=-1.553)$ than altitude $(\mathrm{df}=5$, AIC $=2.465)$ based on the linear mixed effects model (LME). According to the linear model, we found that precipitation was not related to the number of ant species richness per tree (alpha diversity, Table 3, Figure 2a) and beta diversity on the tree (Table 3, Figure 2b). However, precipitation was closely correlated with the dissimilarity distance among cacao trees on each plot. Increasing precipitation was followed by increasing dissimilarity of ant communities on the tree in the cacao agroforestry systems (Table 3, Figure 2c).

Table 3. Linear model between precipitation and alpha diversity, beta diversity and community similarity in each stratum, based on 16 cacao agroforestry plots.

\begin{tabular}{|l|l|l|l|}
\hline \multirow{2}{*}{ Parameters } & \multicolumn{2}{|c|}{ Strata } \\
\cline { 2 - 4 } & \multicolumn{1}{|c|}{ Total } & \multicolumn{1}{|c|}{ Tree } & \multicolumn{1}{c|}{ Soil } \\
\hline Alpha diversity & $\begin{array}{l}\mathrm{r}^{2}=-0.071, \mathrm{~F}_{1,14}=0.003, \\
\mathrm{P}=0.954\end{array}$ & $\begin{array}{l}\mathrm{r}^{2}=-0.036, \mathrm{~F}_{1,14}=0.481, \\
\mathrm{P}=0.450\end{array}$ & $\begin{array}{l}\mathrm{r}^{2}=-0.067, \mathrm{~F}_{1,14}=0.062, \\
\mathrm{P}=0.808\end{array}$ \\
\hline Beta diversity & $\mathrm{r}^{2}=-0.059, \mathrm{~F}_{1,14}=0.159$, & $\begin{array}{l}\mathrm{r}^{2}=0.047, \mathrm{~F}_{1,14}=1.733, \\
\mathrm{P}=0.209\end{array}$ & $\begin{array}{l}\mathrm{r}^{2}=-0.063, \mathrm{~F}_{1,14}=0.114, \\
\mathrm{P}=0.740\end{array}$ \\
\hline Ant community similarity & $\mathrm{P}=0.697$ & $\mathrm{r}^{2}=0.223, \mathrm{~F}_{1,14}=5.296$, \\
& $\mathrm{P}=0.037$ & $\begin{array}{l}\mathrm{r}^{2}=0.280, \mathrm{~F}_{1,14}=6.828, \\
\mathrm{P}=0.021\end{array}$ & $\begin{array}{l}\mathrm{r}^{2}=-0.071, \mathrm{~F}_{1,14}=0.009, \\
\mathrm{P}=0.927\end{array}$ \\
\hline
\end{tabular}


Figure 2. Linear model between precipitation and (a) the mean number species per tree (alpha diversity, $\left.\mathrm{r}^{2}=-0.036, \mathrm{~F}_{1,14}=0.481, \mathrm{P}=0.450\right)$, (b) beta diversity $\left(\mathrm{r}^{2}=0.047\right.$, $\left.\mathrm{F}_{1,14}=1.733, \mathrm{P}=0.209\right)$ and $(\mathbf{c})$ community dissimilarity $\left(\mathrm{r}^{2}=0.280, \mathrm{~F}_{1,14}=6.828\right.$, $\mathrm{P}=0.021$ ) based on species found on all 10 trees per plot.

(a)

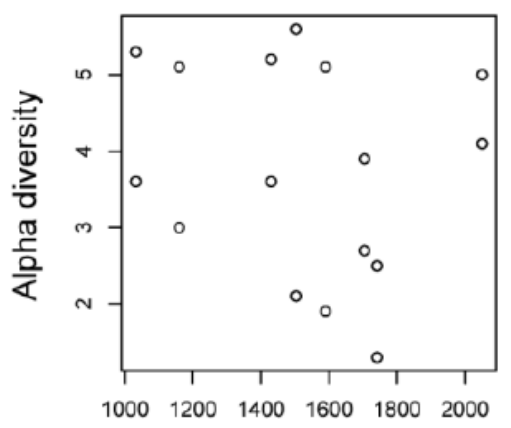

(b)

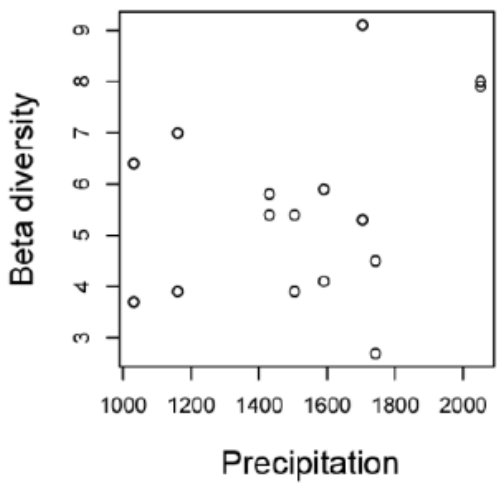

(c)

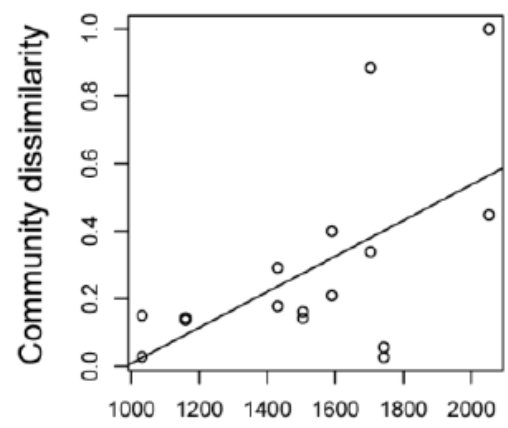

\subsection{Ant species Responses to Precipitation Gradients}

Based on logit regressions for each species, we found that three ant species were related to the precipitation gradients. Crematogaster sp.04 ( $\mathrm{df}=1$, Chi-square $=3.84, \mathrm{P}=0.04$, Figure 3a) and Tapinoma melanocephalum $(\mathrm{df}=1$, Chi-square $=4.59, \mathrm{P}=0.03$, Figure $3 \mathrm{c}$ ) was mainly found in cacao agroforestry with low precipitation (Figure 3c). In contrast, Dolichoderus sp.01 was mainly found in cacao plots with high precipitation $(\mathrm{df}=1$, Chi-square $=5.06, \mathrm{P}=0.02$, Figure $3 \mathrm{~b}$ ). The dominant Dolichoderinae, Philidris cordata, did not show a clear pattern related to precipitation $(\mathrm{df}=1$, Chi-square $=2.41, \mathrm{P}=0.12$, Figure $3 \mathrm{~d}$ ).

Figure 3. Logit regression of ant species with precipitation. (a) Crematogaster sp.04 $(\mathrm{df}=1$, Chi-square=3.84, $\mathrm{P}=0.04$ ), (b) Dolichoderus sp.01 ( $\mathrm{df}=1$, Chi-square=5.06, $\mathrm{P}=0.02$ ), (c) Tapinoma melanochephalum $(\mathrm{df}=1$, Chi-square $=4.59, \mathrm{P}=0.03)$ and $(\mathrm{d})$ Philidris cordata $(\mathrm{df}=1$, Chi-square $=2.41, \mathrm{P}=0.12)$.

(a) Crematogaster sp.04

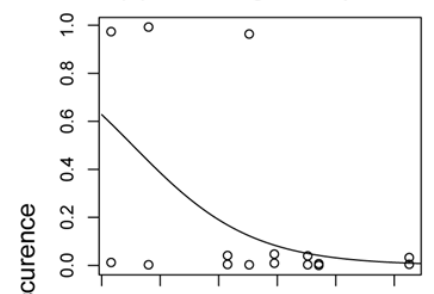

(c) T. melanocephalum

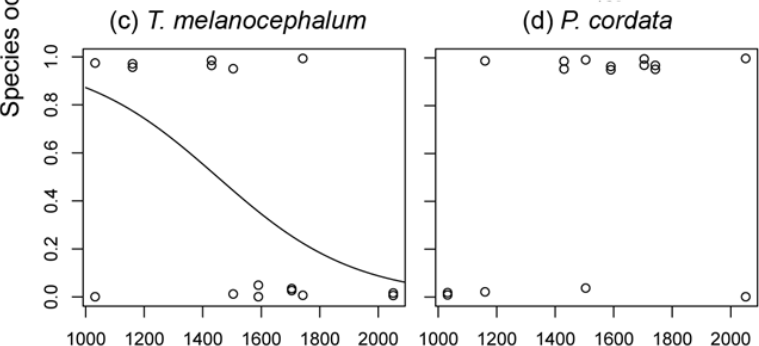

Precipitation

(b) Dolichoderus sp.01

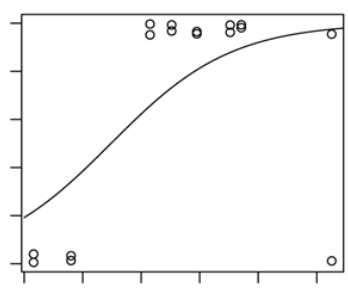

(d) P. cordata

$$
\text { (1) }
$$




\section{Discussion}

Our results showed that higher levels of precipitation were associated with higher dissimilarity, but not species richness, of ant communities in cacao agroforestry systems, whereas land-use changes such as losses of shade trees from the cacao agroforestry systems were not related to ant community dissimilarity or diversity. These findings support the results of Wielgoss et al. [12] in the same study region that decreasing shade trees did not affect ant diversity. However, the study by Bos et al. [11] showed that reduced numbers of shade trees can negatively affect ant diversity, in particular of forest ants, in cacao agroforestry. In the study region of Bos et al. [11], but not Wielgoss et al. [12], natural rainforest surrounded their cacao agroforestry systems. Adjacent rainforests (of the national park) provide high forest ant diversity colonizing cacao agroforestry if characterized by high canopy cover from shade-trees. Therefore, shade trees presumably to be particularly important when rainforest habitat is surrounding cacao agroforestry as a nearby source of forest ants. In this study, the cacao agroforestry systems were not surrounded by, but rather isolated from rainforests, explaining why shade-tree level was not a predictor of ant diversity.

Precipitation did not affect number of ant species per tree (alpha diversity) in cacao agroforestry. This result is similar to that of Delsinne et al. [22], who did not find a relationship between precipitation and local ant species richness in arid ecosystems. In our research, the gradient of precipitation was limited (1032 to $2051 \mathrm{~mm} /$ year), which may explain why alpha diversity did not show a positive correlation of precipitation and ant diversity [23,24]. Nevertheless, we found that increasing precipitation decreased similarity of ant communities in the cacao agroforestry systems.

High precipitation may influence ant communities because of its negative relationship to ant nesting site availability, which is an important stressor for ants [25]. Nesting site limitation can shape ant community composition, affecting co-existence in addition to factors such as competition, environmental stress and disturbance [26]. In addition, higher precipitation caused higher heterogeneity of ant communities, which should be due to higher heterogeneity of cacao tree growth when drought stress is no longer a dominant and homogenizing factor. Reduced precipitation can be an important stress shaping ant communities in a similar way, i.e., converging ant communities, whereas higher precipitation appeared to allow divergence of ant community structure across trees. Higher precipitation is part of environmental instability affecting the similarity of coexisting species [27].

The ant species differed in their response to the precipitation level. Dolichoderus sp.01 tended to be mainly found in cacao agroforestry with higher precipitation. As generalized foragers and distributed mainly in tropical region [28], this species can be expected to suffer most from El Nino (ENSO) droughts, which are common in the region [29]. In contrast, T. melanocephalum, a tramp or human commensal species [30] and Crematogaster sp.04, an arboreal species and nesting in hollow tree trunks [28] were only found in cacao agroforestry with low precipitation, benefiting from droughts. The dominant and invasive species $P$. cordata was not affected by high precipitation and drought, which may be a reason why this species spread widely and became dominant in cacao agroforestry in Sulawesi. 


\section{Conclusions}

Land-use intensity and precipitation gradients did not affect the ant diversity per cacao tree (alpha diversity) and beta diversity in agroforestry systems in Sulawesi. However, high precipitation enhanced ant community dissimilarity, presumably via increased heterogeneity in cacao growth with increasing precipitation and subsequent differences in ant colonization, with ant species responding differently to precipitation level. Our results show that changes of precipitation, which are expected to occur in the study region due to El Nino (ENSO) droughts, should contribute to the homogenization of ant community structure.

\section{Acknowledgments}

Thanks to our field assistants (Fifin, Moh. Fadlan, Akhmad Syakur and Hadiprayitno) and our laboratory assistants (Nur Ivon and Dewi Utaminingsih). Thanks to the owners of cacao agroforestry in Berdikari (Yosias Nthu and Yosep Sapangan), Sintuwu (Tahana M. Suari and Iskandar), Bulili (Sofyan and Tahang), Pandere (Kunci and Nusrin Abd. Samad), Sidondo (Asran Hadoha and H. Manno), Boladangko (Hamzah and Toruba), Toro (Faldin) and Lempelero (Mursan and Pohabe). Thanks also to the staff of the Center for Tropical Forest Margin (CTFM), University of Tadulako, especially to Pak Abdul Rauf and Mbak Anti who were helping with administration during the research. This research project was funded by the German Science Foundation (DFG), Bogor Agricultural University (IPB), and Directorate General of Higher Education, Ministry of National Education of the Republic of Indonesia.

\section{References}

1. Sala, O.E.; Chapin, F.S.; Armesto, J.J.; Berlow, E.; Bloomfield, J.; Dirzo, R.; Huber-Sanwald, E.; Huenneke, L.F.; Jackson, R.B.; Kinzig, A.; et al. Biodiversity-Global biodiversity scenarios for the year 2100. Science 2000, 287, 1770-1774.

2. Lovejoy, T.E. Climate change. In Conservation Biology for All; Sodhi, N.S., Ehrlich, P.R., Eds.; Oxford University Press: Oxford, UK, 2010; pp. 153-162.

3. Hellmann, J.J.; Byers, J.E.; Bierwagen, B.G.; Dukes, J.S. Five potential consequences of climate change for invasive species. Conserv. Biol. 2008, 22, 534-543.

4. Tylianakis, J.M.; Didham, R.K.; Bascompte, J.; Wardle, D.A. Global change and species interactions in terrestrial ecosystems. Ecol. Lett. 2008, 11, 1351-1363.

5. Gornall, J.; Betts, R.; Burke, E.; Clark, R.; Camp, J.; Willett, K.; Wiltshire, A. Implications of climate change for agricultural productivity in the early twenty-first century. Philos. Trans. R. Soc. Lond. Ser. B 2010, 365, 2973-2989.

6. Bhagwat, S.A.; Willis, K.J.; Birks, H.J.B.; Whittaker, R.J. Agroforestry: a refuge for tropical biodiversity? Trends Ecol. Evol. 2008, 23, 261-267.

7. Tscharntke, T.; Clough, Y.; Bhagwat, S.A.; Buchori, D.; Faust, H.; Hertel, D.; Holscher, D.; Juhrbandt, J.; Kessler, M.; Perfecto, I.; Scherber, C.; Schroth, G.; Veldkamp, E.; Wanger, T.C. Multifunctional shade-tree management in tropical agroforestry landscapes- a review. J. Appl. Ecol. 2011, 48, 619-629. 
8. Clough, Y.; Barkmann, J.; Juhrbandt, J.; Kessler, M.; Wanger, T.C.; Anshary, A.; Buchori, D.; Cicuzza, D.; Darras, K.; Putra, D.D.; et al. Combining high biodiversity with high yields in tropical agroforests. Proc. Natl. Acad. Sci. USA 2011, 108, 8311-8316.

9. Wanger, T.C.; Rauf, A.; Schwarze, S. Pesticides and tropical biodiversity. Front. Ecol. Environ. 2010, 8, 178-179.

10. Philpott, S.M.; Armbrecht, I. Biodiversity in tropical agroforests and the ecological role of ants and ant diversity in predatory function. Ecol. Entomol. 2006, 31, 369-377.

11. Bos, M.M.; Steffan-Dewenter, I.; Tscharntke, T. The contribution of cacao agroforests to the conservation of lower canopy ant and beetle diversity in Indonesia. Biodivers. Conserv. 2007, 16, 2429-2444.

12. Wielgoss, A.; Tscharntke, T.; Buchori, D.; Fiala, B.; Clough, Y. Temperature and a dominant dolichoderine ant species affect ant diversity in Indonesian cacao plantations. Agric. Ecosyst. Environ. 2010, 135, 253-259.

13. Bestelmeyer, B.T.; Agosti, D.; Alonso, L.E.; Brandão, C.R.F.; Brown, W.L., Jr.; Delabie, J.H.C.; Silvestre, R. Field techniques for the study of ground-dwelling ants: an overview, description, and evaluation. In Ants: Standard Methods for Measuring and Monitoring Biodiversity; Agosti, D., Majer, J.D., Alonso, L.E., Schultz, T.R., Eds.; Smithsonian Institution Press: Washington, DC, USA, 2000; pp. 122-144.

14. Bolton, B. Identification Guide to the Ant Genera of the World; Harvard University Press: Cambridge, UK, 1994; p. 222.

15. Lattke, J.E. Specimen processing: building and curating an ant collection. In Ants: Standard Methods for Measuring and Monitoring Biodiversity; Agosti, D., Majer, J.D., Alonso, L.E., Schultz, T.R., Eds.; Smithsonian Institution Press: Washington, DC, USA, 2000; pp. 155-171.

16. Antweb. Available online: http://www.antweb.org (accessed on 20 January 2010).

17. Colwell, R.K.; Coddington, J.A. Estimating terrestrial biodiversity through extrapolation. Philos. Trans. R. Soc. Lond. Ser. B 1994, 345, 101-118.

18. Mantel, N. The detection of disease clustering and a generalized regression approach. Cancer Res. 1967, 27, 209-220.

19. Legendre, P.; Legendre, L. Numerical ecology, 2nd English ed.; Elsevier: Dordrecht, The Netherlands, 1998.

20. Gering, J.C.; Crist, T.O. The alpha-beta-regional relationship: providing new insights into localregional patterns of species richness and scale dependence of diversity components. Ecol. Lett. 2002, 5, 433-444.

21. R Development Core Team. R: A Language and Environment for Statistical Computing; R Foundation for Statistical Computing: Vienna, Austria, 2011.

22. Delsinne, T.; Roisin, Y.; Herbauts, J.; Leponce, M. Ant diversity along a wide rainfall gradient in the Paraguayan dry Chaco. J. Arid Environ. 2010, 74, 1149-1155.

23. Dunn, R.R.; Agosti, D.; Andersen, A.N.; Arnan, X.; Bruhl, C.A.; Cerdá, X.; Ellison, A.M.; Fisher, B.L.; Fitzpatrick, M.C.; Gibb, H.; et al. Climatic drivers of hemispheric asymmetry in global patterns of ant species richness. Ecol. Lett. 2009, 12, 324-333.

24. Dunn, R.R.; Guenard, B.; Weiser, M.D.; Sanders, N.J. Geographic gradients. In Ant Ecology; Lach, L., Parr, C.L., Abbott, K.L., Eds.; Oxford University Press: New York, NY, USA, 2010; pp. 38-58. 
25. Andersen, A.N. Global ecology of rainforest ants: functional groups in relation to environmental stress and disturbance. In Ants: Standard Methods for Measuring and Monitoring Biodiversity; Agosti, D., Majer, J.D., Alonso, L.E., Schultz, T.R., Eds.; Smithsonian Institution Press: Washington, DC, USA, 2000; pp. 25-34.

26. Andersen, A.N. A classification of Australian ant communities, based on functional groups which parallel plant life-forms in relation to stress and disturbance. J. Biogeogr. 1995, 22, 15-29.

27. MacArthur, R.; Levins, R. The limiting similarity, convergence, and divergence of coexisting species. Am. Nat. 1967, 101, 377-385.

28. Brown, W.L., Jr. Diversity of ants. In Ants: Standard Methods for Measuring and Monitoring Biodiversity; Agosti, D., Majer, J.D., Alonso, L.E., Schultz, T.R., Eds.; Smithsonian Institution Press: Washington, DC, USA, 2000; pp. 45-79.

29. Gerold, G.; Leemhuis, C. Effects of "ENSO-events" and rainforest conversion on river discharge in Central Sulawesi (Indonesia). In Tropical Rainforests and Agroforests under Global Change: Ecological and Socio-economic Valuations; Tscharntke, T., Leuschner, C., Veldkamp, E., Faust, H., Guhardja, E., Bidin, A., Eds.; Springer-Verlag: Berlin, 2010; pp. 327-350.

30. McGlynn, T.P. The worldwide transfer of ants: geographical distribution and ecological invasions. J. Biogeogr. 1999, 26, 535-548.

\section{Supplementary Material}

Table S1. The occurrence of ant species (proportion of trees occupied, 10 cacao trees observed) collected in the 16 cacao agroforestry plots in eight villages (1: Berdikari, 2: Sintuwu, 3: Bulili, 4: Pandere, 5: Sidondo, 6: Boladangko, 7: Toro, and 8: Lempelero) with different land-use (A: shaded, B: unshaded cacao agroforestry). Morphospecies were based on the different of external morphology.

\begin{tabular}{|c|c|c|c|c|c|c|c|c|c|c|c|c|c|c|c|c|c|}
\hline \multirow{3}{*}{ No } & \multirow{3}{*}{ Species } & \multicolumn{16}{|c|}{ Village } \\
\hline & & \multicolumn{2}{|c|}{1} & \multicolumn{2}{|c|}{2} & \multicolumn{2}{|c|}{3} & \multicolumn{2}{|c|}{4} & \multicolumn{2}{|c|}{5} & \multicolumn{2}{|c|}{6} & \multicolumn{2}{|c|}{7} & \multicolumn{2}{|c|}{8} \\
\hline & & $\mathbf{A}$ & B & $\mathbf{A}$ & B & $\mathbf{A}$ & B & $\mathbf{A}$ & B & $\mathbf{A}$ & B & $\mathbf{A}$ & B & $\mathbf{A}$ & B & $\mathbf{A}$ & B \\
\hline \multicolumn{18}{|c|}{ Dolichoderinae } \\
\hline 1. & Dolichoderus sp.01 & & 0.5 & 0.4 & 0.5 & 0.2 & 0.7 & & & & & 0.9 & 0.2 & 0.5 & 0.2 & 0.1 & 0.2 \\
\hline 2. & Dolichoderus thoracicus & & & & & & 1 & & & 1 & & & & & & & \\
\hline 3. & $\begin{array}{l}\text { Philidris cordata } \\
\text { Tapinoma }\end{array}$ & & 0.7 & 1 & 1 & 1 & & 1 & & & & 0.7 & 1 & 0.9 & 1 & 1 & 1 \\
\hline 4. & melanocephalum & & & 0.2 & 0.7 & & 0.3 & 0.3 & 0.9 & 1 & & & & & & & 0.2 \\
\hline 5. & Tapinoma sp.01 & 0.4 & 1 & 0.2 & & & & 0.7 & & & 0.9 & 0.1 & 0.7 & 0.8 & 0.7 & & 0.2 \\
\hline 6. & Technomyrmex albipes & & & 0.3 & & & 1 & & & & & 0.9 & & 0.2 & & & \\
\hline 7. & Technomyrmex sp.01 & & & & & & & & & & & & & 0.3 & & & \\
\hline \multicolumn{18}{|c|}{ Formicinae } \\
\hline 8. & Anoplolepis gracilipes & & 0.1 & & & & & & 0.5 & & 1 & 0.8 & 0.3 & 0.5 & 0.4 & & \\
\hline 9. & Camponotus recticulatus & & 0.4 & 0.9 & 0.2 & 0.7 & 0.1 & 0.1 & & & & 0.3 & 0.6 & 0.1 & & & 0.5 \\
\hline 10. & Camponotus sp.01 & 0.9 & & & 0.1 & 0.1 & 0.1 & 0.1 & 0.1 & & & & 0.1 & 0.1 & & & 0.1 \\
\hline 11. & Camponotus sp.02 & & & & 0.1 & & & & & & & & & & & & \\
\hline 12. & Echinopla lineata & 0.1 & & 0.8 & & 0.5 & & & & & & & & & & & \\
\hline 13. & Oecophylla smaragdina & & 0.1 & 0.2 & 0.1 & & & & 1 & & & & & & & & \\
\hline
\end{tabular}


Table S1. Cont.

\begin{tabular}{|c|c|c|c|c|c|c|c|c|c|c|c|c|c|c|c|c|c|}
\hline \multirow{3}{*}{ No } & \multirow{3}{*}{ Species } & \multicolumn{16}{|c|}{ Village } \\
\hline & & \multicolumn{2}{|c|}{1} & \multicolumn{2}{|c|}{2} & \multicolumn{2}{|c|}{3} & \multicolumn{2}{|c|}{4} & \multicolumn{2}{|c|}{5} & \multicolumn{2}{|c|}{6} & \multicolumn{2}{|c|}{7} & \multicolumn{2}{|c|}{8} \\
\hline & & $\mathbf{A}$ & B & $\mathbf{A}$ & B & $\mathbf{A}$ & B & $\mathbf{A}$ & B & $\mathbf{A}$ & B & $\mathbf{A}$ & B & $\mathbf{A}$ & B & $\mathbf{A}$ & B \\
\hline 14. & Paratrechina longicornis & & & & & & & 1 & & & & & & & & & 0.4 \\
\hline 15. & Nylanderia sp.01 & 1 & & 0.9 & 1 & 1 & 1 & 0.6 & 1 & 0.8 & & 1 & 0.8 & 1 & 1 & 1 & 0.9 \\
\hline 16. & Nylanderia sp.02 & & 1 & & & & & & & & & & & & & & \\
\hline 17. & Nylanderia sp.03 & & & & & & & & & 0.7 & & & & & & & \\
\hline 18. & Nylanderia sp.04 & 0.1 & 0.8 & & & & & 0.3 & & & 1 & & & & & & \\
\hline 19. & Plagiolepis sp.01 & 0.9 & & & & & & & & & & & & & & & \\
\hline 20. & Polyrachis abdominalis & 0.3 & & & & & & & & 0.2 & & & & & & & \\
\hline 21. & Polyrachis dives & & & 0.7 & 0.5 & 0.3 & & 0.2 & & & & & & 0.2 & & & 0.1 \\
\hline 22. & Polyrachis sp.01 & & & 0.3 & 0.4 & & & & & & & & & & & & \\
\hline 23. & Polyrachis sp.02 & & & 0.5 & & & & & & & & & 0.4 & & & & \\
\hline 24. & Polyrachis sp.03 & 0.1 & & & & & & & & & & & & & & & \\
\hline 25. & Polyrachis sp.04 & & & & & 0.2 & & & & & & & & & & & \\
\hline 26. & Polyrachis sp.05 & 0.8 & & & & & & & & & & & & & & & \\
\hline 27. & Polyrachis sp.06 & & & 0.1 & & & & & & & & & & 0.2 & 0.1 & & \\
\hline 28. & Polyrachis sp.07 & 0.4 & & & & & & & & & & & & & & & \\
\hline 29. & Pseudolasius sp.01 & & & & & & & & & & & 0.2 & & 0.3 & 0.1 & & \\
\hline 30. & Pseudolasius sp.02 & & & & & & & & & & & & & & 0.3 & & \\
\hline
\end{tabular}

\section{Myrmicinae}

31. Crematogaster sp.01

0.6

$\begin{array}{ll}0.1 & 0.7\end{array}$

0.6

32. Crematogaster sp.02

33. Crematogaster sp.03

$\begin{array}{ll}0.6 & 0.1\end{array}$

$\begin{array}{lllll}0.1 & 0.2 & 0.2 & 0.6 & 0.1\end{array}$

$0.1 \quad 0.7$

$0.7 \quad 0.3$

$\begin{array}{lll}0.2 & 0.8 & 0.2\end{array}$

0.6

34. Crematogaster sp.04

0.2

$\begin{array}{lll}0.2 & 0.9 & 0.8\end{array}$

35. Crematogaster sp.05

36. Monomorium floricola

0.7

0.7

$\begin{array}{ll}0.3 & 0.1\end{array}$

37. Monomorium sp.01

38. Monomorium sp.02

0.4

39. Monomorium sp.03

40. Monomorium sp.04

41. Monomorium sp.05

42. Monomorium sp.06

43. Pheidole sp. 01

44. Pheidole sp.02

45. Pheidole sp.03

46. Pheidole sp.04

47. Pheidole sp.05

48. Pheidole sp.06

49. Pheidole sp.07

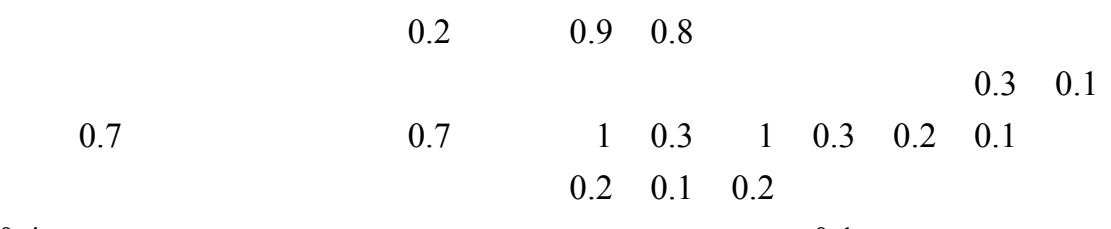

0.2

0.1

0.1

$\begin{array}{ll}0.1 & 0.2\end{array}$

$\begin{array}{llllllllllllllllll}0.3 & 0.7 & 0.1 & 0.3 & 0.3 & 0.3 & 0.7 & 0.7 & 0.7 & 0.6 & 0.3 & & & & 0.1 & 0.5 & 0.2 \\ 0.9 & & & & 0.1 & 0.1 & 0.1 & & & & 0.1 & & & 0.6 & 0.4 & 0.1 \\ 0.4 & 0.9 & & & & & 0.7 & & 0.7 & 0.5 & 0.1 & 0.4 & 0.1 & 0.3 & 0.1 & \end{array}$

0.1
$\begin{array}{ll}0.1 & 0.6\end{array}$
0.5
0.1
$\begin{array}{lll}0.2 & 0.2 & 0.2\end{array}$
$\begin{array}{ll}0.4 & 0.1\end{array}$

0.1 
Table S1. Cont.

\begin{tabular}{|c|c|c|c|c|c|c|c|c|c|c|c|c|c|c|c|c|c|}
\hline \multirow{3}{*}{ No } & \multirow{3}{*}{ Species } & \multicolumn{16}{|c|}{ Village } \\
\hline & & \multicolumn{2}{|c|}{1} & \multicolumn{2}{|c|}{2} & \multicolumn{2}{|c|}{3} & \multicolumn{2}{|c|}{4} & \multicolumn{2}{|c|}{5} & \multicolumn{2}{|c|}{6} & \multicolumn{2}{|c|}{7} & \multicolumn{2}{|c|}{8} \\
\hline & & $\mathbf{A}$ & B & $\mathbf{A}$ & $\mathbf{B}$ & $\mathbf{A}$ & B & $\mathbf{A}$ & B & $\mathbf{A}$ & B & $\mathbf{A}$ & B & $\mathbf{A}$ & B & $\mathbf{A}$ & B \\
\hline 50. & Pheidole sp.08 & & & 0.1 & 0.1 & & & & & & & & & & & & \\
\hline 51. & Pheidologeton sp.01 & & & & & & & & & & & 0.1 & & & & & \\
\hline 52. & Pyramica paradoxa & & & & & & & & & 0.1 & & & & & & & \\
\hline 53. & Solenopsis geminata & & & & & & & & & 0.4 & & & & & & & \\
\hline 54. & Strumigenys sp.01 & & & & & & & & & 0.1 & & & 0.1 & & 0.1 & & 0.1 \\
\hline 55. & Tetramorium bicarinatum & & 0.9 & & & & & & & 0.1 & 0.4 & & & & & & \\
\hline 56. & Tetramorium pasificum & 0.2 & & & & & 0.9 & & & & & 0.5 & & 0.3 & & & \\
\hline 57. & Tetramorium smithi & & & & & & 0.4 & & & & 0.3 & & 0.1 & 0.1 & 0.1 & & 0.1 \\
\hline 58. & Tetramorium sp.01 & & & & & & & & 0.5 & & & & & & & & \\
\hline 59. & Tetramorium sp.02 & & 0.2 & & & & & & & & 0.2 & & & & & & \\
\hline 60. & Tetramorium sp.03 & 0.2 & & & & & & & & 0.3 & & & & & & & \\
\hline 61. & Tetramorium sp.04 & 0.4 & & & & 0.1 & & & & 0.1 & & & & & & & \\
\hline 62. & Tetramorium sp.05 & & & 0.1 & 0.1 & & & & & 0.3 & & & 0.1 & 0.1 & & 0.1 & 0.1 \\
\hline 63. & Tetramorium sp.06 & & & & & & & & & & & 0.3 & & 0.4 & & & 0.1 \\
\hline 64. & Tetramorium sp.07 & & & & & & & & & & & & & 0.3 & & & \\
\hline 65. & Tetramorium sp.08 & & & 0.2 & 0.1 & & & & & & & & & & & & \\
\hline
\end{tabular}

\begin{tabular}{|c|c|c|c|c|c|c|c|c|c|c|c|c|c|c|c|}
\hline Ponerinae & & & & & & & & & & & & & & & \\
\hline 66. Anochetus graeffei & & & & & & 0.3 & 0.3 & 0.4 & 0.2 & & 0.3 & & 0.2 & & \\
\hline Diacamma rugosum & & & & & & & 0.4 & 0.1 & 0.6 & 0.9 & & & & & \\
\hline Hypoponera sp.01 & 0.2 & & 0.1 & 0.1 & & & 0.2 & & & 0.1 & & & 0.2 & & \\
\hline Hypoponera sp.02 & & & 0.8 & 0.9 & 0.3 & 0.1 & & & & 0.6 & 0.8 & 0.9 & 0.5 & 0.7 & 0.3 \\
\hline 70. Hypoponera sp.03 & & & 0.1 & & & & & & 0.4 & 0.2 & & & & & \\
\hline 71. Hypoponera sp.04 & & & & & & & & 0.2 & & & & & & & 1 \\
\hline 72. Leptogenys sp.01 & 0.1 & & 0.2 & & & & & & & & & 0.1 & 0.3 & & \\
\hline 73. Odontomachus simillimus & 0.2 & 0.5 & 0.7 & 0.7 & 1 & & 0.1 & 0.4 & 0.3 & 0.7 & 0.3 & 1 & 0.9 & 1 & 0.2 \\
\hline 74. Pachycondyla sp.01 & 0.4 & & & & & 0.1 & 0.2 & & & 0.2 & & 0.1 & & 0.2 & 0.4 \\
\hline Pachycondyla sp.02 & 0.1 & & & & & & & & & & & & & & \\
\hline 76. Pachycondyla sp.03 & & & & & & & & 0.2 & & & & & & & \\
\hline Pachycondyla sp.04 & & & & & & & & & 0.1 & & & & & & \\
\hline 78. Platythyrea sp.01 & & & 0.1 & 0.1 & 0.1 & & 0.2 & 0.1 & & 0.1 & & & & & \\
\hline
\end{tabular}

Pseudomyrmicinae

79. Tetraponera sp.01

0.1

80. Tetraponera sp.02 
Figure S1. Correlation between precipitation and altitude of the 16 plots of the study area $\left(\mathrm{F}_{1,14}=21.47, \mathrm{P}=0.0004, \mathrm{r}^{2}=0.58\right)$.

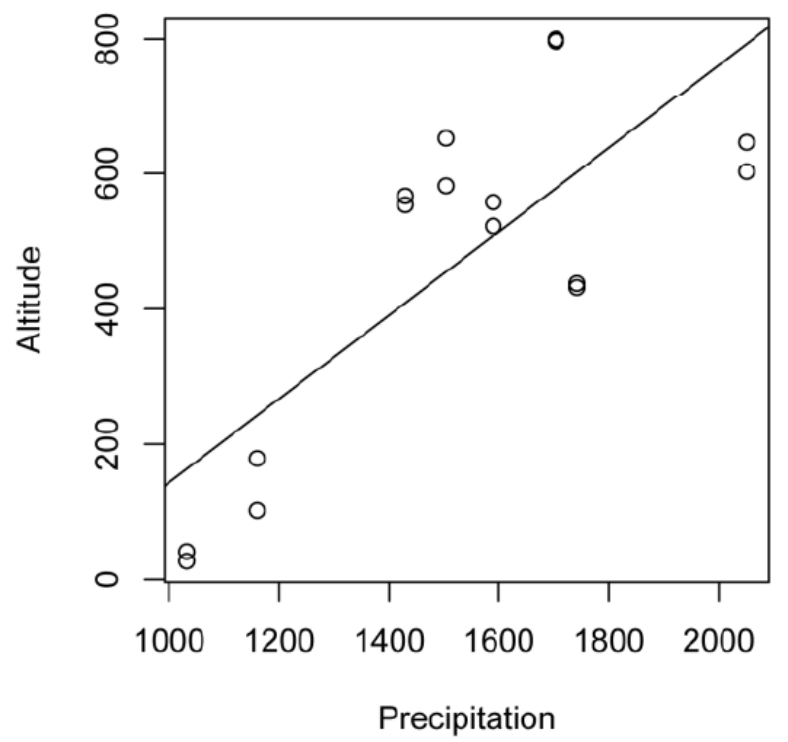

(C) 2013 by the authors; licensee MDPI, Basel, Switzerland. This article is an open access article distributed under the terms and conditions of the Creative Commons Attribution license (http://creativecommons.org/licenses/by/3.0/). 